\title{
Analýza průřezového tématu Environmentální výchova v Rámcovém vzdělávacím programu pro základní vzdělávání
}

\author{
Jan Činčera
}

Envigogika 2009/IV/1 - Recenzované články/ Reviewed Papers

Publikováno/Published 31. 05. 2009

DOI: http://dx.doi.org/10.14712/18023061.33

\begin{abstract}
Abstrakt:
Článek analyzuje průřezové téma Environmentální výchova v Rámcovém vzdělávacím programu pro základní vzdělávání. Analýza je provedena čtyřmi komplementárními postupy. V první části je téma porovnáno se zahraničními standardy pomocí nástroje pro analýzu environmentálních kurikulí Environmental Education Curriculum Inventory. Ve druhé části byla analyzována vnitřní integrita tématu. Ve třetí byl posouzen jazyk tématu a jeho vztah $\mathrm{k}$ antropocentrickým, resp. neantropocentrickým hodnotám. V poslední části byla vyhodnocena relevance dokumentu z hlediska teorií environmentálně odpovědného chování. Analýza ukázala, že prưřezové téma pro environmentální výchovu na základních školách není kompatibilní s mezinárodními standardy, je jen částečně vnitřně integrováno, je hodnotově neutrální a nekoresponduje s teoriemi proenvironmentálního chování.
\end{abstract}

\section{Klíčová slova:}

Rámcový vzdělávací program, základní vzdělávání, environmentální výchova

\section{Abstract:}

The article analyses cross-cutting themes of Environmental Education in General Educational Program for Elementary Education. The analysis was done using four complementary approaches. In the first part the area was compared with an international standard, the Environmental Education Curriculum Inventory. In the second part the article evaluates the inner integrity of the area. The third part assesses the language of the area and its connections to anthropocentric, or respectively non-anthropocentric values. The last part evaluates the area from the point of view of theories of responsible environmental education.

The analysis shows that the area of environmental education is not compatible with international standards, its inner integrity is only partial, it is value-neutral and does not correspond with the theories of responsible environmental education.

\section{Key words:}

General Educational Program, elementary education, environmental education 


\section{Úvod}

Jedním ze základních prostředků pro zajištění kvality výchovy je vymezení standardů. Standardy pomáhají v procesu tvorby vlastních vzdělávacích programů, protože definují cíle a rámcový obsah kurikula, mohou doporučit některé metodické postupy a do určité míry mohou suplovat roli evaluace programů. Standardy se používají po celém světě, jsou uplatňovány $v$ prostředí formální i neformální výchovy pro řadu výchovně vzdělávacích oblastí.

Vzhledem k vlivu standardů na př́slušnou výchovně vzdělávací oblast by měla být samozřejmostí také jejich kritická evaluace. Cílem článku je analyzovat a vyhodnotit průřezové téma environmentální výchova jako klíčový dokument vymezující environmentální výchovu v oblasti základního vzdělávání.

\section{Standardy environmentální výchovy v zahraničí a v České republice}

Přestože téměř v každé zemi můžeme najít specifické standardy pro environmentální výchovu, vychází mezinárodní vědecká komunita nejčastěji ze čtyř základních cílových úrovní environmentální výchovy vymezených Hungerfordem, Peytonem a Wilkem (1980). Těmi jsou:

1. Ekologické základy, soustřed'ující se na porozumění základním ekologickým principům;

2. Porozumění environmentální konceptům, zaměřenými na vztahy mezi člověkem a životním prostředím;

3. Výzkum a evaluace, ve kterých se rozvíjejí dovednosti žáků;

4. Environmentální akční dovednosti.

Klíčovým faktorem pro podporu tohoto modelu je jeho konzistence s teoriemi odpovědného environmentálního chování. Odpovědné environmentální chování (také proenvironmentální chování) je řadou autorů chápáno jako základní cíl environmentální výchovy. (Hungerford \& Volk, 1990; Emmons, 2007; Hines, Hungerford \& Tomera, 1986) Přestože není jednoznačně definováno, zpravidla se akceptuje Marcinkowského (1997) vymezení základních oblastí, ve kterých jedinec príiímá rozhodnutí s ohledem na zájmy životního prostředí a teorie Hungerforda a Volkové (1990) popisující vztahy mezi proměnnými, které proenvironmentální chování ovlivňují.

Model cílových úrovní environmentální výchovy prošel $v$ průběhu let rozsáhlou diskusí. V připomínkách se objevoval zejména požadavek zahrnout do první úrovně environmentální senzitivitu (Kim, 2003) či další afektivní dispozice, jako je osobní odpovědnost, postoje, hodnoty (Marcinkowski, 1997) nebo smysl pro místo (sense of place) (Ardoin, 2009). Přestože výzkumy ukazují relevanci těchto afektivních proměnných, není zatím vytvořený konsensus ohledně jejich zahrnutí do školního kurikula (Hungerford, Peyton \& Wilke, 1980). Zatímco osobní odpovědnost je již v současnosti zahrnuta do standardů Severoamerické asociace pro environmentální výchovu, environmentální senzitivita zde explicitně uvedena není (Simmons, 2004).

Z modelu vychází i standardy environmentální výchovy Severoamerické asociace pro environmentální výchovu (North American Association for Environmental Education). Podle nich by měly školní programy obsahovat čtyři základní prvky (Simmons, 2004): 
1. dotazovací, analytické a interpretační dovednosti,

2. znalosti environmentálních problémů a systémů,

3. dovednosti pro porozumění a řešení environmentálních konfliktů,

4. osobní a občanskou odpovědnost.

Podle této struktury jsou standardy vymezeny jak pro formální, tak neformální oblast výchovy a vzdělávání. Standardy pro formální vzdělávání jsou dále rozděleny podle věkových kategorií. V každé pak jsou definovány očekávané výstupy žáků na konci př́slušného období.

Z modelu dále vycházejí nástroje pro obsahovou analýzu školních kurikulí. Nejznámějším je Environmental Education Curriculum Inventory z roku 1986. (Volk, 1997) Nástroj postupuje po jednotlivých cílových rovinách, každou člení do několika oblastí a umožňuje bodovat jejich pokrytí ve školním kurikulu na škále 0-4 . V průběhu dalších diskusí byl nástroj přepracován Kimem (2003), který do něj zahrnul oblast environmentální senzitivity a sociálních základů.

V České republice se můžeme setkat s několika různými standardy či doporučeními, které vymezují cíle, obsah či metody environmentální výchovy. V oblasti neformální výchovy jsou to především kvalitativní standardy pro ekologické výukové programy definované Sítí středisek ekologické výchovy Pavučina a cílové a obsahové standardy hnutí Junák - svaz skautů a skautek ČR, tzv. Stezka.

Standardy SSEV Pavučina jsou tvořeny jednak tzv. Ekopedagogovým osmerem (Máchal, Činčera, Daňková \& Broukal, 2008), které definuje hlavní požadavky na programy a středisko, jednak aktuálně vyvíjeným evaluačním nástrojem, Hodnotící tabulkou (Hodnotící tabulka, 2008). Oba nástroje se vztahují především ke kvalitě programu k jeho provedení, realizačním podmínkám ve středisku či zpracování programu.

Skautská stezka se zabývá jak kvalitativními, tak obsahovými požadavky a definuje očekávané výstupy včetně souvisejících indikátorů pro jednotlivé věkové kategorie. Vychází z tématických okruhů, pro které jsou vymezeny základní kompetence a dále specifické výstupy, indikátory a doporučené metody (Žárská, Demlová, Kupka, Klápště, Zajíc \& Šantora, 2008; Klápště, 2008). V oblasti formální výchovy a vzdělávání se můžeme setkat se standardy vyplývajícími z členství školy v určité organizaci či programu. Takovým standardem mohou být pravidla pro získání certifikátu Škola udržitelného rozvoje udělované sdružením Klub ekologické výchovy (Kvasničková, 2007) či Zelená vlajka programu Ekoškola (Sdružení Tereza, 2008).

Nejdůležitějším dokumentem pro oblast formálního vzdělávání jsou Rámcové vzdělávací programy, které definuji cílové kompetence a obsah pro jednotlivé výchovně vzdělávací oblasti pro dané typy škol. Rámcové vzdělávací programy (RVP) jsou v současnosti schváleny pro oblast předškolního vzdělávání, základního vzdělávání, gymnaziálního vzdělávání, pro základní školy speciální a pro některé obory odborného vzdělávání. Environmentální výchova je zastoupena ve všech, přičemž v RVP pro základní a gymnaziální vzdělávání je shrnuta $v$ samostatném prưřezovém tématu, pro oblast odborného vzdělávání je vymezeno průřezové téma Člověk a životní prostředí (RVP, 2009; Metodický pokyn, 2009).

Postavení průřezových témat $v$ RVP neodpovídá přesně postavení závazného standardu. Prưřezová témata standardizují obsah, resp. u prưřezového tématu Environmentální výchova v RVP pro základní vzdělávání (dále jen PT EV) to je povinnost školy zabudovat do svého kurikula každé ze šesti $v$ něm uvedených témat. Současně ale PT ponechávají školám volnost $v$ hloubce jejich naplňování. Podle autora článku Ize ale předpokládat, že PT EV $v$ řadě škol de facto roli standardu hraje a že školy zpracovávají své ŠVP v této oblasti tak, aby cíle i obsah PT v maximální míře naplnily. PT EV tedy 
školám částečně standardizuje obsah environmentální výchovy a slouží jim jako vodítko k jeho samostatnému zpracování.

K environmentální výchově ve školním prostředí se pak vztahují ještě další dokumenty, které RVP $v$ této oblasti vymezují a doplňují. Jde zejména o Metodický pokyn MŠMT $k$ zajištění environmentálního vzdělávání, výchovy a osvěty. Metodický pokyn definuje environmentální výchovu, upřesňuje povinnosti školního koordinátora environmentální výchovy a doporučuje vytvoření školního programu EVVO, který by měl konkretizovat školní vzdělávací program environmentální výchovy (Metodický pokyn, 2008).

Standardizované jsou také požadavky na vzdělání školních koordinátorů environmentální výchovy. Ty jsou definovány Vyhláškou č. 317/2005 Sb. o studiu $k$ výkonu specializovaných činností. Standard vymezuje cíle vzdělávání, kritéria výběru účastníků, rozsah studia a tematické okruhy.

$\checkmark$ dalším textu bude podrobně analyzován jeden $z$ uvedených dokumentů, a to prưřezové téma Environmentální výchova v Rámcovém vzdělávacím programu pro základní vzdělávání.

\section{Popis průřezového tématu Environmentální výchova v RVP pro základní vzdělávání}

Prưřezové téma Environmentální výchova je $v$ dokumentu rozděleno do tři částí (RVP, 2009). Charakteristika průřezového tématu obsahuje obecnou definici environmentální výchovy a vazby tématu k základním vzdělávacím oblastem. Př́nos průřezového tématu $\mathrm{k}$ rozvoji osobnosti žáka je možné chápat jako vymezení očekávaných výstupů programu. (Vzhledem $k$ tomu, že prímo v PT EV nejsou očekávané výstupy explicitně uvedeny, je toto třeba chápat jako subjektivní interpretaci autora článku.) Tyto výstupy jsou rozděleny na oblast kognitivní a konativní (vědomosti, dovednosti, schopnosti) a afektivní (postoje a hodnoty). Poslední částí jsou Tematické okruhy prüřezového tématu. Těmi jsou:

- Ekosystémy

- Základní podmínky života

- Lidské aktivity a problémy životního prostředí

- Vztah člověka k prostředí.

Vztah mezi jednotlivými částmi není $v$ dokumentu přesně vymezen. Lze předpokládat, že definice environmentální výchovy v Charakteristice prưřezového tématu hraje roli obecného cíle, Př́nos prüřezového tématu definuje očekávané výstupy a Tematické okruhy pak obsah učiva. Povinností škol je zařadit do výuky všechny tematické okruhy, rozsah a způsob realizace ale může určovat škola (RVP:88). Toto chápání ale není zcela podložené dikcí RVP, podle kterého Charakteristika prưřezového tématu nedefinuje cíle, ale "význam a postavení průřezového tématu" (RVP:88) a ani Přínosy prưřezového tématu nejsou jednoznačně definovány jako očekávané výstupy. Zda uvedená interpretace odpovídá chápání těchto částí PT EV pedagogickou veřejností by muselo být předmětem dalšího výzkumného šetření.

Jedinou závaznou částí průřezového tématu tedy jsou tematické okruhy, které současně dávají školám značný prostor $\mathrm{k}$ rozhodnutí o míre jejich implementace do školních vzdělávacích programů. 


\section{Metody analýzy průřezového tématu}

Přestože o RVP probíhají ve společnosti rozsáhlé diskuse, nebylo dosud průřezové téma Environmentální výchova dostatečně analyzováno. Hornová (2006) si všímá problému s volností škol při výběru z tematických okruhů a vyslovuje obavu, že se "na pojetí dnešního vzdělávání nic nezmění." Kožoušková (2007) téma srovnává se starším pojetím vzdělávacího programu Základní škola a konstatuje, že se téma soustředí „převážně na vlastní pozorování, praktické činnosti, vyhledávání informací, komunikaci o problémech. Vede žáky k zamyšlení, k vlastnímu názoru a jeho obhajobě. Zakládá si na praktickém využití všech dovedností a vědomostí v běžném životě a na orientaci ve složitém systému společnosti a světa." Podle autorky se prưřezové téma "zaměřuje na dovednosti, jak umět informace získat, porozumět jim, pochopit souvislosti, vytvořit si vlastní názor, ten pak zdůvodnit, ptát se, komunikovat o problémech a mít prostor pro seberealizaci." Práce ale průřezové téma především popisuje.

Z diskusí o souvisejících tématech je třeba uvést analýzu RVP pro gymnaziální vzdělávání zaměřené na problematiku rozvojové výchovy (Dlouhá, 2004). Práce poukazuje na povrchnost zpracování některých témat a nedostatečnou konzistenci mezi cíli a tématy.

Následující analýza se zaměřuje na tyto výzkumné otázky:

- Do jaké míry odpovídá vymezení průřezového tématu Environmentální výchova srovnatelným zahraničním standardům?

- Do jaké míry je průřezové téma vnitřně konzistentní ve vztazích cíle výstupy - témata?

- Jaké postoje a hodnoty vyjadřuje jazyk průřezového tématu?

- Do jaké míry koresponduje zpracování průřezového tématu s relevantními teoriemi odpovědného environmentálního chování?

Pro zodpovězení byly použity následující metody:

- Vyhodnocení průřezového tématu pomocí Environmental Education Curriculum Inventory vinovované variantě Kim Kyung Oka zroku 2003.

- Komparace relevantních proměnných zoblasti cílů (Charakteristika), výstupů (Př́nosy) a učiva (Témata).

- Sémantická analýza jazyka dokumentu porovnávající četnost antropocentrické vs. neantropocentrické terminologie.

- Porovnání proměnných zastoupených $v$ průřezovém tématu $s$ teorií plánovaného chování I. Ajzena, odpovědného environmentálního chování R. Hungerforda a T. Volkové a Sternovy Value-Belief-Norm teorie.

\section{Prezentace výsledků}

\section{Komparace prưřezového tématu se zahraničními standardy}

V této části analýzy bylo posuzováno, do jaké míry prưřezové téma odpovídá srovnatelným zahraničním standardům. Pro komparaci byl vybrán Environmental Education Curriculum Inventory ve variantě Kim Kyung Oka z roku 2003. Výhodou nástroje je, že vychází z relevantních výzkumů vztahů mezi jednotlivými proměnnými environmentální gramotnosti a současně je $v$ zahraničí běžně používán. Nástroj pracuje se čtyřmi úrovněmi cílư environmentální výchovy (Hungerford, Peyton \& Wilke, 1980), u kterých definuje dílčí hodnocené kategorie (viz. Tabulky 1-4). Míra jejich zastoupení v posuzovaném materiálu 
se hodnotí na škále 0-4, kde 0 znamená „vůbec ne", 1 „málo", 2 "do určité míry", 3 „docela dobře" a 4 „velmi dobře".

Průřezové téma bylo hodnoceno podle míry, do jaké jsou požadované kategorie Environmental Education Curriculum Inventory zastoupeny v jeho tématických okruzích. Protože tématické okruhy RVP jsou uspořádány jiným zpưsobem, než hodnocené kategorie v Environmental Education Curriculum Inventory, byla z tématických okruhů nejprve vybrána dílčí témata (dále označovaná jako "sémantické jednotky" - ucelené textové jednotky nesoucí význam), která byla následně přiřazována k hodnoceným kategoriím. Při hodnocení každé kategorie pak byla zvážena jak četnost přiřazených sémantických jednotek, tak míra jejího obsahového pokrytí. Environmental Education Curriculum Inventory je kvalitativní hodnotící nástroj který nemůže eliminovat subjektivitu hodnocení. $Z$ tohoto důvodu jsou $v$ článku uvedeny kompletní tabulky 1-4 obsahující přehled sémantických jednotek zařazených do jednotlivých kategorií i počet přidělených bodů. Cílem hodnocení není určit přesný index míry konzistence PT EV s Environmental Education Curriculum Inventory, ale spíše upozornit na existující rozpory. Vyšší objektivitu by mohlo zajistit hodnocení týmem expertů, který by podle prezentované metodiky mohl navázat kritickým rozborem dalších klíčových kurikulárních dokumentů a standardů $v$ oblasti environmentální výchovy.

Tab. č. 1. Vyhodnocení průřezového tématu na úrovni základů.

\begin{tabular}{|c|c|c|}
\hline Úroveň 1. Základy & Sémantické jednotky & Body \\
\hline \multicolumn{3}{|l|}{$\begin{array}{l}\text { Do jaké míry nabízí posuzovaný program } \\
\text { žákưm príležitosti rozvinout } \\
\text { a osvojit si následující oblasti? }\end{array}$} \\
\hline \multicolumn{3}{|l|}{ 1. Environmentální senzitivita. } \\
\hline $\begin{array}{l}\text { Povzbudit empatii žáků k přírodě } \\
\text { (emocionální, nikoliv ve smyslu } \\
\text { racionálního porozumění). Poskytnutí } \\
\text { přiležitosti k reflexi svého vztahu } \\
\text { k přírodě. }\end{array}$ & & 0 \\
\hline \multicolumn{3}{|l|}{ 2. Sociální základy. } \\
\hline $\begin{array}{l}\text { A. Technologické. Dopady technologií na } \\
\text { společnost a životní prostředí. }\end{array}$ & & 0 \\
\hline $\begin{array}{l}\text { B. Kulturní. Vliv kultury na lidské vnímání } \\
\text { hodnoty technologií, přírodních zdrojů, } \\
\text { jejich užití a environmentální integritu. } \\
\text { Související sociální dopady na životní } \\
\text { prostředí. }\end{array}$ & & 0 \\
\hline $\begin{array}{l}\text { C. Politické. Role vlády v péči o životní } \\
\text { prostředí. Práva a odpovědnost občanů } \\
\text { ve vztahu k životnímu prostředí. }\end{array}$ & $\begin{array}{l}\text { ‥dlouhodobé programy zaměřené k } \\
\text { růsstu ekologického vědomí veřejnosti } \\
\text { (Státní program EVVO, Agenda } 21 \mathrm{EU} \text { ) } \\
\text { a akce (Den životního prostředí OSN, } \\
\text { Den Země apod.). }\end{array}$ & 2 \\
\hline $\begin{array}{l}\text { D. Právní. Právní normy a jejich aplikace } \\
\text { na management životního prostředí. } \\
\text { Práva jednotlivce a skupin použít právní } \\
\text { nástroje pro řešení environmentálních } \\
\text { konfliktů. }\end{array}$ & $\begin{array}{l}\text {...vliv právních a ekonomických } \\
\text { nástrojů na vztahy průmyslu } \\
\text { k ochraně životního prostředí. }\end{array}$ & 1 \\
\hline
\end{tabular}


E. Ekonomické. Role výroby, distribuce a spotřeby ve využívání prírodních zdrojů. Další ekonomické dopady na životní prostředí. ...les (les v našem prostředí, produkční a mimoprodukční významy lesa); pole (význam, změny okolní krajiny vlivem člověka, zpưsoby hospodaření na nich, pole a jejich okolí); vodní zdroje (lidské aktivity spojené

$\mathrm{s}$ vodním hospodářstvím, důležitost pro krajinnou ekologii), význam vody pro lidské aktivity, prírodní zdroje (zdroje surovinové

a energetické, jejich vyčerpatelnost, vlivy na prostředí, principy hospodaření s přírodními zdroji, význam a způsoby získávání a využívání prrírodních zdrojů v okolí), zemědělství a životní prostředí, ekologické zemědělství. Průmysl a životní prostředí (průmyslová revoluce a demografický vývoj, vlivy průmyslu na prostředí, zpracovávané materiály a jejich působení, průmysl a udržitelný rozvoj společnosti.

...lidské sídlo - město - vesnice (umělý ekosystém, jeho funkce

a vztahy k okolí, aplikace na místní podmínky); kulturní krajina (pochopení hlubokého ovlivnění přírody $v$ průběhu vzniku civilizace až po dnešek), změny $v$ krajině (krajina dříve a dnes, vliv lidských aktivit, jejich reflexe a perspektivy).

Environmentální dopady lidských sídel. Geografie, urbanizace, územní plánování a megapole.

\section{Ekologické základy.}

A. Populace. Populační dynamika (narození, růst, změny a jejich dopady, smrt, vyhynutí atd.)

B. Ekosystémy. Struktura, interakce mezi živými organizmy a neživou prírodou a její dopady (přirozené změny, sukcese, adaptace, atd.). ...voda (vztahy vlastností vody a života, význam vody pro lidské aktivity, ochrana její čistoty, pitná voda ve světě a u nás, zpưsoby řešení), les (les $v$ našem prostředí, produkční a mimoprodukční významy lesa); pole (význam, změny okolní krajiny vlivem člověka, zpưsoby hospodaření na nich, pole a jejich okolí); vodní zdroje (lidské aktivity spojené

s vodním hospodářstvím, důležitost pro krajinnou ekologii); moře (druhová odlišnost, význam pro biosféru, mořské řasy a kyslík, cyklus oxidu uhličitého) a tropický deštný les (porovnání, druhová rozmanitost, ohrožování, globální význam a význam pro nás); ekosystémy - biodiverzita 


\begin{tabular}{|l|l|c|}
\hline & $\begin{array}{l}\text { (funkce ekosystémů, význam } \\
\text { biodiverzity, její úrovně, ohrožování } \\
\text { a ochrana ve světě a u nás). }\end{array}$ & \\
\hline $\begin{array}{l}\text { C Energie a chemické cykly. Jak energie } \\
\text { a chemické látky prochází př́rodním } \\
\text { systémem (vodní cyklus, kyslíkový } \\
\text { cyklus, toky energie, znečištujících látek } \\
\text { atd.) }\end{array}$ & $\begin{array}{l}\text {..cyklus oxidu uhličitého, voda } \\
\text { (vztahy vlastností vody a života }\end{array}$ & 1 \\
\hline $\begin{array}{l}\text { D. Rovnováha př́rody. Tendence } \\
\text { prírodních systémú vracet se po } \\
\text { přirozeném zásahu či lidském znečištění } \\
\text { postupně do rovnovážného stavu. }\end{array}$ & & 0 \\
\hline Celkový součet: & & 14 \\
\hline Průměrný zisk (součet získaných bodů: počet témat): & 1,27 \\
\hline
\end{tabular}

Úroveň základů je v tematických okruzích pokryta pouze málo. Žádná sémantická jednotka neodpovídá environmentální senzitivitě, přestože je zařazena mezi Př́ínosy prüřezového tématu. Lépe jsou zastoupeny sociální základy. Tematické okruhy se podrobně zabývají ekonomickým využíváním přírodních zdrojů a využíváním krajiny člověkem, v menší míre rolí vlády $v$ ochraně životního prostředí. Témata nepokrývají oblast technologických a kulturních vlivů člověka na životní prostředí.

Důvodem nízkého bodování oblasti ekologických základů je, že tematické okruhy sice věnuji velký prostor popisu jednotlivých složek životního prostředí, ale jen okrajově se věnují základním ekologickým procesům, které naopak tvoří jádro ekologických základů $\checkmark$ Environmental Education Curriculum Inventory a odpovídají první cílové úrovni podle Hungerforda, Peytona a Wilka (1980). Tento rozpor má paradigmatický rozměr: české standardy se soustředí na popisy a tedy znalosti, zatímco americké na procesy a tedy porozumění.

Můžeme předpokládat, že žáci škol, které sestaví svůj školní vzdělávací program zcela podle doporučení RVP, budou rozumět tomu, jak ekonomické a urbanistické aktivity ovlivňují životní prostředí i jaké politické a právní nástroje jsou v oblasti životního prostředí využívány. Budou také pravděpodobně znát a umět charakterizovat jednotlivé složky životního prostředí. Škola ale nemusí přiliš ovlivnit jejich vztah k životnímu prostředí ani jejich porozumění základním principům fungování prírody.

Tab. č. 2. Vyhodnocení průřezového tématu na úrovni pojmového porozumění.

\begin{tabular}{|c|c|c|}
\hline Úroveň 2. Pojmové porozumění & Sémantické jednotky & Body \\
\hline $\begin{array}{l}\text { Do jaké míry umožňuje posuzovaný } \\
\text { program žákům osvojit si následující oblasti? }\end{array}$ & & \\
\hline $\begin{array}{l}\text { 1. Vysvětlení, jak lidská činnost (osobní } \\
\text { chování a kulturní aktivity, tj. náboženské, } \\
\text { ekonomické, politické, sociální a další) } \\
\text { ovlivňuje životní prostředí. }\end{array}$ & $\begin{array}{l}\text {...voda - způsoby řešení, půda } \\
\text { (propojenost složek prostředí, zdroj } \\
\text { výživy, ohrožení půdy, rekultivace } \\
\text { a situace v okolí, změny v potřebě } \\
\text { zemědělské půdy, nové funkce } \\
\text { zemědělství v krajině, ochrana } \\
\text { biologických druhů (důvody ochrany } \\
\text { a způsoby ochrany jednotlivých } \\
\text { druhů), ekosystémy - biodiverzita }\end{array}$ & 4 \\
\hline
\end{tabular}




\begin{tabular}{|c|c|c|}
\hline & \begin{tabular}{|l} 
(funkce ekosystémů, význam \\
biodiverzity, její úrovně, ohrožování \\
a ochrana ve světě a u nás), energie \\
(energie a život, vliv energetických \\
zdrojů na společenský rozvoj, \\
využívání energie, možnosti \\
a způsoby šetření, místní podmínky). \\
Přírodní zdroje (zdroje surovinové \\
a energetické, jejich vyčerpatelnost, \\
vlivy na prostředí, principy \\
hospodaření s prírodními zdroji, \\
význam a způsoby získávání \\
a využívání př́rodních zdrojů \\
v okolí), odpady a hospodaření \\
s odpady (odpady a příroda, principy \\
a zpưsoby hospodaření s odpady, \\
druhotné suroviny); náš životní styl \\
(spotřeba věcí, energie, odpady, \\
zpưsoby jednání a vlivy na \\
prostředí).
\end{tabular} & \\
\hline $\begin{array}{l}\text { 2. Seznámení s environmentálními problémy } \\
\text { i environmentálními konflikty (na lokální, } \\
\text { národní i globální úrovni). }\end{array}$ & \begin{tabular}{|l}
...obec (přírodní zdroje, jejich původ, \\
zpưsoby využívání a řešení \\
odpadového hospodářství, příroda \\
a kultura obce a její ochrana, \\
zajištóování ochrany životního \\
prostředí v obci - instituce, nevládní \\
organizace, lidé); aktuální (lokální) \\
ekologický problém (příklad \\
problému, jeho příčina, důsledky, \\
souvislosti, možnosti a způsoby \\
řešení, hodnocení, vlastní názor, \\
jeho zdůvodňování a prezentace), \\
prostředí a zdraví (rozmanitost vlivů \\
prostředí na zdraví, jejich komplexní \\
a synergické působení, možnosti \\
a způsoby ochrany zdraví); \\
nerovnoměrnost života na Zemi \\
(rozdílné podmínky prostředí a \\
rozdílný společenský vývoj na Zemi, \\
příčiny a důsledky zvyšování rozdílů \\
globalizace a principy udržitelnosti \\
rozvoje, příklady jejich uplatňování \\
ve světě, u nás)
\end{tabular} & 4 \\
\hline $\begin{array}{l}\text { 3. Seznámení s dostupnými alternativními } \\
\text { řešeními environmentálních problémů } \\
\text { a konfliktů z předchozího bodu. }\end{array}$ & $\begin{array}{l}\text { energie (energie a život, vliv } \\
\text { energetických zdrojů na společenský } \\
\text { rozvoj, využívání energie, možnosti } \\
\text { a způsoby šetření, místní podmínky), } \\
\text { ochrana biologických druhů (důvody } \\
\text { ochrany a způsoby ochrany } \\
\text { jednotlivých druhů), rekultivace, } \\
\text { přírodní zdroje (zdroje surovinové } \\
\text { a energetické, jejich vyčerpatelnost, } \\
\text { vlivy na prostředí, principy } \\
\text { hospodaření s prírodními zdroji, } \\
\text { význam a způsoby získávání } \\
\text { a využívání přírodních zdrojů } \\
\text { v okolí), ekologické zemědělství; }\end{array}$ & 2 \\
\hline
\end{tabular}




\begin{tabular}{|l|l|l|}
\hline & $\begin{array}{l}\text { Ochrana přírody a kulturních } \\
\text { památek (význam ochrany prírody } \\
\text { a kulturních památek; právní řešení } \\
\text { u nás, v EU a ve světě, př́klady } \\
\text { z okolí, zásada předběžné opatrnosti; } \\
\text { ochrana prírody při masových } \\
\text { sportovních akcích - zásady MOV) }\end{array}$ & \\
\hline $\begin{array}{l}\text { 4. Seznámení se spektrem přístupů, které } \\
\text { vycházejí z různých hodnot a přesvědčení } \\
\text { osob zainteresovaných do } \\
\text { environmentálního konfliktu a s nutností } \\
\text { jejich vyjasnění jako předpokladu pro } \\
\text { přijmutí souvisejících rozhodnutí. }\end{array}$ & & 0 \\
\hline $\begin{array}{l}\text { 5. Seznámení s konkrétními } \\
\text { environmentálními konflikty a jejich kritická } \\
\text { analýza založená na identifikaci jednotlivých } \\
\text { stran konfliktu a jejich názorových pozic, } \\
\text { přesvědčení a hodnot. }\end{array}$ & & 0 \\
\hline Celkový součet: & & 10 \\
\hline Průměrný zisk (součet získaných bodů: počet témat): & 2 \\
\hline
\end{tabular}

Průřezové téma se podrobně zaměřuje na popisy vlivu člověka na životní prostředí a na přehled lokálních i globálních environmentálních problémů. Nižší hodnocení dostalo v kategorii Seznámení s dostupnými alternativními řešeními. Dưvodem je neprovázanost mezi popisem problémů a jejich řešeními. Ta je pro Environmental Education Curriculum Inventory stěžejní. Nástroj vychází z předpokladu, že v rámci efektivní environmentální výchovy žáci zkoumají konkrétní problémy a jejich možná řešení. (Hungerford \& Volk, 1990) Tím dochází k posílení „akční orientace" kurikula a k tomu, že žáci nejsou frustrováni pocitem bezmoci tvárí v tvář problémům současného světa (Mogensen, 2004). Toto propojení z průřezového tématu nevyplývá. Dokument doporučuje seznámit žáky s výčtem rưzných problémů a výčtem obecných strategií environmentální politiky, chybí ale jasné propojení: problém - řešení.

Prưřezové téma dále nerozlišuje mezi environmentálními problémy a konflikty. Podle Volkové (1997) „environmentální problémy mohou mít přirozený původ nebo mohou být způsobeny lidmi, konflikty vznikají kolem interpretace problému." Rozlišování mezi problémy a konflikty je důležitým předpokladem pro pochopení konfliktů jako oblastí, ve kterých se střetávají hodnoty a postoje jednotlivých stran. Takové chápání pak je předpokladem pro efektivní zapojování do řešení konfliktů (Mogensen, 2004). $\checkmark$ prưřezovém tématu chybí zaměření na identifikaci různých stran konfliktu a spektra souvisejících hodnotových orientací jejích protagonistů.

Druhá cílová oblast environmentální výchovy je v PT EV pro základní školy zastoupena pouze "do určité míry". Školy, které podle něj sestaví svưj školní vzdělávací plán, sice seznámí žáky s řadou environmentálních problémů i s tím, jak člověk ovlivňuje životní prostředí, a do určité míry i se zásadami udržitelné politiky. Žáci se ale už nemusí naučit chápat environmentální konflikty jako místa střetu nositelů různých hodnot a postojů $v$ diskusích o využívání krajiny, což může zkomplikovat jejich porozumění vlastním možnostem zapojení se do jejich řešení. 
Tab. č. 3. Vyhodnocení průřezového tématu na úrovni výzkumu.

\begin{tabular}{|c|c|}
\hline Úroveň 3. Výzkum & Body \\
\hline Do jaké míry umožňuje posuzovaný program žákům osvojit si následující oblasti? & 0 \\
\hline $\begin{array}{l}\text { 1. Schopnost shromáždit informace související s environmentálním konfliktem od } \\
\text { klíčových osob a z dalších sekundárních zdrojů (kontaktováním expertů, rešerší } \\
\text { atd.). }\end{array}$ & 0 \\
\hline 2. Schopnost formulovat výzkumnou otázku pro analýzu konfliktu. & 0 \\
\hline $\begin{array}{l}\text { 3. Schopnost shromááždit informace o environmentálním konfliktu pomocí vlastního } \\
\text { prüzkumu, dotazníků, rozhovorů a jejich kombinace (vyvinout výzkumný nástroj, } \\
\text { naplánovat metody sběru dat a sesbírat data z primárních zdrojü). }\end{array}$ & 0 \\
\hline $\begin{array}{l}\text { 4. Schopnost organizovat data do tabulek a grafů a interpretovat je formulováním } \\
\text { závěrů, souvislostí a doporučení. }\end{array}$ & 0 \\
\hline $\begin{array}{l}\text { 5. Schopnost prezentovat výsledky svého výzkumu spolužákům nebo jiným členům } \\
\text { komunity. }\end{array}$ & 0 \\
\hline Celkový součet: & 0 \\
\hline Průměrný zisk (součet získaných bodů: počet témat): & 0 \\
\hline
\end{tabular}

Úroveň výzkumu není v PT EV vůbec zastoupena. Školám, které sestaví svůj školní vzdělávací program identicky podle tematických okruhů, tedy hrozí, že nebudou u žáků dostatečně rozvíjet schopnosti a dovednosti související se sběrem, analýzou a prezentací informací o životním prostředí.

Tab. č. 4. Vyhodnocení prưř̌zového tématu na úrovni environmentálního jednání.

Úroveň 4. Environmentální jednání

1. Vyjadřuje potřebu odpovědného environmentálního chování pro řešení environmentálních konfliktů.

2. Ukazuje porozumění různým úrovním environmentálního jednání (na úrovni jednotlivců, skupin, organizací atd.).

3. Uvádí konkrétní příklady pro jednotlivé kategorie environmentálního jednání (přesvědčování, spotřeba, politická akce, právní akce, ekomanagement).

4. Nabízí různé scénáře a prípadové studie, které studentovi umožní aplikovat znalosti environmentálního jednání a vybrat odpovědné environmentální jednání.

5. Určí společenské a ekologické náklady a prínosy zvolených environmentálních akcí.

6. Umožňuje jednotlivcům i skupinám vyzkoušet vhodnou formu environmentálního jednání na vybraný a analyzovaný environmentální problém.

Celkový součet:

Průměrný zisk (součet získaných bodů: počet témat):

Ani úroveň jednání není v prưřezovém tématu zastoupena. Školy, které budou postupovat podle tematických okruhů, tedy pravděpodobně nepovedou žáky 
k samostatnému hledání, volbě a aplikaci vhodných strategií k řešení vybraných environmentálních problémů.

Srovnání průřezového tématu Environmentální výchova se zahraničním Environmental Education Curriculum Inventory prokázalo jen velmi malou míru shody. Rozdíly mezi oběma standardy jsou hluboké a mají paradigmatický rozměr. Zahraniční standard je výrazně orientován na samostatnou iniciativu žáků a jejich zapojení do „akce". PT EV směřuje ke znalostem environmentální problematiky a popisu ekosystémů a složek životního prostředí. Zahraniční standard odráží normativní (centrální pozice studenta) až v některých rysech pluralistické pojetí (kritické vyhodnocování různých názorů, zapojení žáků do rešení místních problémů) environmentální výchovy, český pak výrazně její faktografickou tradici. (Östman \& Öhman, 2007).

\section{Analýza vnitřní konzistence průřezového tématu}

Ve druhé části analýzy se zaměříme na konzistenci cílů, očekávaných výstupů a učiva vymezených $v$ prưřezovém tématu.

Cíli (goals) se v kontextu environmentální výchovy nejčastěji rozumí obecné stanovisko vyjadřující očekávání, jaké změny program přinese. Vycházejí ze společenských potřeb pocitóvaných v oblasti environmentální výchovy na regionální, národní či mezinárodní úrovni (Bennett, 1989; Sellers, 2007; Schueller, Yaffee, Higgs, Mogelgaard, \& DeMattia, 2006).

Očekávané výstupy (objectives, outcomes; dále také jen „výstupy") jsou zpravidla chápány jako specifické a měřitelné výsledky programu směřující k dosažení jeho obecných cílů. Jsou to tedy určité změny v porozumění, znalostech, postojích, dovednostech či chování, které vznikly v důsledku programu (Department of Environment and Conservation, 2004; Schueller, Yaffee, Higgs, Mogelgaard, \& DeMattia, 2006).

Zpracování programu pak předpokládá postup „od cílů k prostředkům”, tj. od vymezení obecných cílů, přes specifikaci výstupů až k volbě učiva a vhodných metod výuky. Program je možné považovat za vnitřně konzistentní, pokud každá jednotka učiva koresponduje surčitými výstupy a současně výstupy jsou propojeny s obecnými cíli programu.

Analýzu vnitřní konzistence prưřezového tématu komplikují dvě okolnosti. První je absence jasného vymezení, které jeho části jsou chápány jako "cíle" a „výstupy". Přestože ale prưřezové téma nemá cíle a výstupy přesně identifikované, autor z jeho uspořádání předpokládá, že roli cíle zde hraje definice environmentální výchovy z Charakteristiky průřezového tématu, role výstupư je popsána v Př́nosech průřezového tématu $k$ rozvoji osobnosti žáka a učiva jako témata uspořádaná do jednotlivých tematických okruhů.

Druhou komplikaci představuje fakt, že jedinou povinnou součástí průřezového tématu jsou tematické okruhy (tedy "učivo"). Tato skutečnost je do značné míry paradoxní. Přestože rámcové vzdělávací programy vychází z postupu „od cílů k prostředkům" (roli cílů hrají klíčové kompetence, definované jako "souhrn vědomostí, dovedností, schopností, postojů a hodnot dưležitých pro osobní rozvoj a uplatnění každého člena společnosti." (RVP:14)), prưřezové téma vychází z opačné logiky.

Uvedené skutečnosti limitují výsledky analýzy vnitřní konzistence standardu, které je proto možno chápat pouze jako orientační.

V první fázi analýzy byly vybrány všechny sémantické jednotky z definice environmentální výchovy v „Charakteristice" a přiřazeny do kategorie "Cíle". V rámci kategorie pak byly uspořádány pod jednotlivé kódy vyjadřující jejich význam. Protože definice $v$ Charakteristice byla poměrně krátká, jsou některé kódy syceny pouze jedinou sémantickou jednotkou, ke dvěma kódům byly přiděleny dvě sémantické jednotky. Pro další práci pak byly kódy setříděny podle svého zaměření na učení, resp. znalosti, postoje 
a dovednosti žáků a na chování žáků. To odpovídá druhé a třetí rovině evaluace podle Kirkpatrickova modelu ${ }^{1}$ (podle Hoganová, 2003; Simmons, 2008) Přiřazení sémantických jednotek ke kódům po jednotlivých kategoriích (cíle, výstupy, učivo) je znázorněno v tabulkách 5-7.

Tab. č. 5. Přehled kódů v kategorii Cíle.

\begin{tabular}{|c|c|}
\hline Kódy & Sémantické jednotky \\
\hline \multicolumn{2}{|l|}{ Kognitivní } \\
\hline $\begin{array}{l}\text { Porozumění provázanosti } \\
\text { člověka a prostředí }\end{array}$ & $\begin{array}{l}\text {...pochopení komplexnosti a složitosti vztahů člověka } \\
\text { a životního prostředí. } \\
\text {...sledovat a uvědomovat si vztahy mezi člověkem } \\
\text { a prostředím při prímém poznávání aktuálních hledisek } \\
\text { ekologických, ekonomických, vědeckotechnických, politických } \\
\text { a občanských, hledisek časových i prostorových. }\end{array}$ \\
\hline Znalost akčních strategií & $\begin{array}{l}\text { Sledovat a uvědomovat si ... možnosti různých variant řešení } \\
\text { environmentálních problémů. }\end{array}$ \\
\hline \multicolumn{2}{|l|}{$\begin{array}{l}\text { Afektivní } \\
\text { (postoje a hodnoty) }\end{array}$} \\
\hline $\begin{array}{l}\text { Přijetí udržitelného } \\
\text { rozvoje }\end{array}$ & $\begin{array}{l}\text {...pochopení nezbytnosti postupného přechodu k udržitelnému } \\
\text { rozvoji společnosti. }\end{array}$ \\
\hline $\begin{array}{l}\text { Přijetí vlastní } \\
\text { odpovědnosti }\end{array}$ & $\begin{array}{l}\text {...poznání významu odpovědnosti za jednání společnosti } \\
\text { i každého jedince. }\end{array}$ \\
\hline Hodnoty & Ovlivňuje ... hodnotovou orientaci žáků. \\
\hline \multicolumn{2}{|l|}{ Chování } \\
\hline $\begin{array}{l}\text { Proenvironmentální } \\
\text { chování }\end{array}$ & $\begin{array}{l}\text { Vede jedince k aktivní účasti na ochraně a utváření prostředí. } \\
\text { Ovlivňuje... životní styl žáků. }\end{array}$ \\
\hline
\end{tabular}

Z přehledu kódů v kategorii cílů je zřejmé, že standard zcela pomíjí konativní rovinu a klade důraz na rovinu kognitivní a afektivní. Standard si klade za cíl proenvironmentální chování žáků, které ale vymezuje značně vágně. Ze samotných cílư není patrné, jaké oblasti proenvironmentálního chování by měly být v rámci základního vzdělávání ovlivněny.

Do kategorie „Výstupy" byly přiřazeny sémantické jednotky z "Přínosů". Významové jednotky byly kódovány stejným zpưsobem, jako u "Cílů".

\footnotetext{
${ }^{1}$ Kirkpatrickův model rozlišuje čtyři základní úrovně evaluace: reaktivní (spokojenost cílové skupiny), učení (získané znalosti, dovednosti, postoje a hodnoty), transferovou (dlouhodobé změny chování) a dlouhodobé dopady (vliv na místní komunitu, životní prostředí atd.).
} 
Tab. č. 6. Přehled kódů v kategorii Výstupy.

\begin{tabular}{|c|c|}
\hline Kódy & Sémantické jednotky \\
\hline \multicolumn{2}{|l|}{ Kognitivní } \\
\hline Ekologické principy & $\begin{array}{l}\text {...porozumění souvislostem v biosféře. } \\
\text {...uvědomování si podmínek života. }\end{array}$ \\
\hline Člověk a prostředí & $\begin{array}{l}\text {...porozumění ... vztahům člověka a prostředí. } \\
\text {...porozumění ... důsledkům lidských činností na prostředí. } \\
\text {...uvědomování si ...možností jejich ohrožování. } \\
\text {...poznávání a chápání souvislostí mezi vývojem lidské } \\
\text { populace a vztahy k prostředí v rưzných oblastech světa. } \\
\text {...seznamuje s principy udržitelnosti rozvoje společnosti. }\end{array}$ \\
\hline \multirow{2}{*}{ Znalost akčních strategií } & $\begin{array}{l}\text { Poskytuje znalosti ... nezbytné pro každodenní žádoucí jednání } \\
\text { občana vưči prostředí. }\end{array}$ \\
\hline & $\begin{array}{l}\text {...ukazuje modelové příklady jednání z hlediska životního } \\
\text { prostředí a udržitelného rozvoje žádoucích i nežádoucích. }\end{array}$ \\
\hline \multicolumn{2}{|l|}{$\begin{array}{l}\text { Afektivní } \\
\text { (postoje a hodnoty) }\end{array}$} \\
\hline Vědomí odpovědnosti & $\begin{array}{l}\text {...pochopení souvislostí mezi lokálními a globálními problémy } \\
\text { a vlastní odpovědností ve vztazích k prostředí. } \\
\text {...vede k odpovědnosti ve vztahu k biosféře, k ochraně prírody } \\
\text { a přírodních zdrojů. }\end{array}$ \\
\hline $\begin{array}{l}\text { Environmentální } \\
\text { senzitivita }\end{array}$ & $\begin{array}{l}\text {...přispívá k vnímání života jako nejvyšší hodnoty. } \\
\text {..prřispívá k ... vnímání estetických hodnot prostředí. }\end{array}$ \\
\hline $\begin{array}{l}\text { Souhlas s konceptem } \\
\text { udržitelného rozvoje }\end{array}$ & $\begin{array}{l}\text {...vede k pochopení významu a nezbytnosti udržitelného } \\
\text { rozvoje jako pozitivní perspektivy dalšího vývoje lidské } \\
\text { společnosti. }\end{array}$ \\
\hline \multicolumn{2}{|l|}{ Konativní (dovednosti) } \\
\hline Akční kompetence & $\begin{array}{l}\text { Poskytuje ... dovednosti a pěstuje návyky nezbytné pro } \\
\text { každodenní žádoucí jednání občana vǔči prostředí. } \\
\text {...napomáhá rozvíjení spolupráce v péči o životní prostředí na } \\
\text { místní, regionální, evropské i mezinárodní úrovni. } \\
\text {...učí komunikovat o problémech životního prostředí, } \\
\text { vyjadřovat, racionálně obhajovat a zdưvodňovat své názory } \\
\text { a stanoviska. }\end{array}$ \\
\hline Výzkumné dovednosti & $\begin{array}{l}\text {...učí hodnotit objektivnost a závažnost informací týkajících se } \\
\text { ekologických problémů. }\end{array}$ \\
\hline \multicolumn{2}{|l|}{ Chování } \\
\hline Ekomanagement & $\begin{array}{l}\text {...podněcuje aktivitu, tvořivost, toleranci, vstřícnost } \\
\text { a ohleduplnost ve vztahu k prostředí. } \\
\text {...vede k vnímavému a citlivému přístupu k přírodě } \\
\text { a prírodnímu a kulturnímu dědictví. }\end{array}$ \\
\hline Zdravý životní styl & ...přispívá k utváření zdravého životního stylu. \\
\hline Politicko-právní chování & $\begin{array}{l}\text {...vede } \mathrm{k} \text { angažovanosti v řešení problémů spojených } \\
\text { s ochranou životního prostředí. }\end{array}$ \\
\hline
\end{tabular}


Do „Učiva" byly zařazeny sémantické jednotky z „Tematických okruhů", které byly opět kategorizovány. Přestože PT EV definuje čtyři tematické okruhy, bylo pro potřebu analýzy nutné vytvořit nové kategorie. Protože chování není předmětem, ale výsledkem učení (respektive rozvíjení určitých znalosti, dovedností, hodnot a postojů), není tato rovina do kategorie Učiva zahrnuta.

Tab. č. 7. Přehled kódů v kategorii Učivo.

\begin{tabular}{|c|c|}
\hline Kódy & Sémantické jednotky \\
\hline \multicolumn{2}{|l|}{ Kognitivní } \\
\hline Typy ekosystémů & $\begin{array}{l}\text { Les (les v našem prostředí, produkční a mimoprodukční } \\
\text { významy lesa); pole (význam ...). } \\
\text { Moře (druhová odlišnost, význam pro biosféru, mořské řasy } \\
\text { a kyslík, cyklus oxidu uhličitého). } \\
\text { Tropický deštný les (porovnání, druhová rozmanitost). } \\
\text { Lidské sídlo - město - vesnice (umělý ekosystém, jeho funkce } \\
\text { a vztahy k okolí, aplikace na místní podmínky). } \\
\text { Kulturní krajina. } \\
\text { Ekosystémy - biodiverzita (funkce ekosystémů, význam } \\
\text { biodiverzity, její úrovně). }\end{array}$ \\
\hline $\begin{array}{l}\text { Složky životního } \\
\text { prostředí }\end{array}$ & $\begin{array}{l}\text { Vodní zdroje, voda. } \\
\text { Ovzduší. } \\
\text { Půda. }\end{array}$ \\
\hline Člověk a ekosystémy & 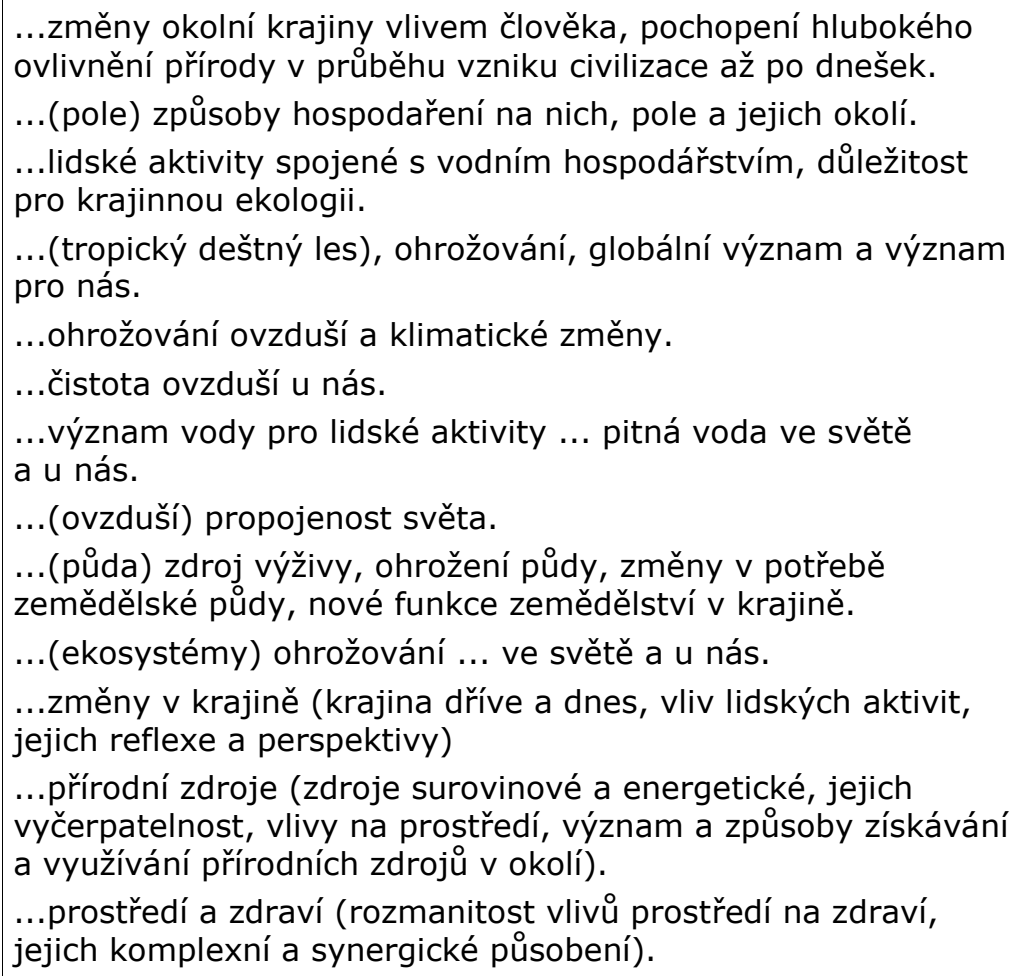 \\
\hline Ekologické principy & $\begin{array}{l}\text {...vztahy vlastností vody a života. } \\
\text {...(ovzduší) význam pro život na Zemi. } \\
\text {...(půda) propojenost složek prostredí. } \\
\text {...energie (energie a život). }\end{array}$ \\
\hline
\end{tabular}




\begin{tabular}{|c|c|}
\hline Ekonomické aktivity & $\begin{array}{l}\text {...vliv energetických zdrojů na společenský rozvoj, využíání } \\
\text { energie, místní podmínky. } \\
\text {...doprava a životní prostředí (význam a vývoj, energetické } \\
\text { zdroje dopravy a její vlivy na prostředí, druhy dopravy } \\
\text { a ekologická zátěž, doprava a globalizace). } \\
\text {...průmysl a životní prostředí (průmyslová revoluce } \\
\text { a demografický vývoj, vlivy prưmyslu na prostředí, } \\
\text { zpracovávané materiály a jejich pưsobení); } \\
\text { odpady a příroda. } \\
\text {...nerovnoměrnost života na Zemi (rozdílné podmínky } \\
\text { prostředí a rozdílný společenský vývoj na Zemi, příčiny } \\
\text { a dưsledky zvyšování rozdílů globalizace). }\end{array}$ \\
\hline $\begin{array}{l}\text { Strategie řešení } \\
\text { problémů }\end{array}$ & 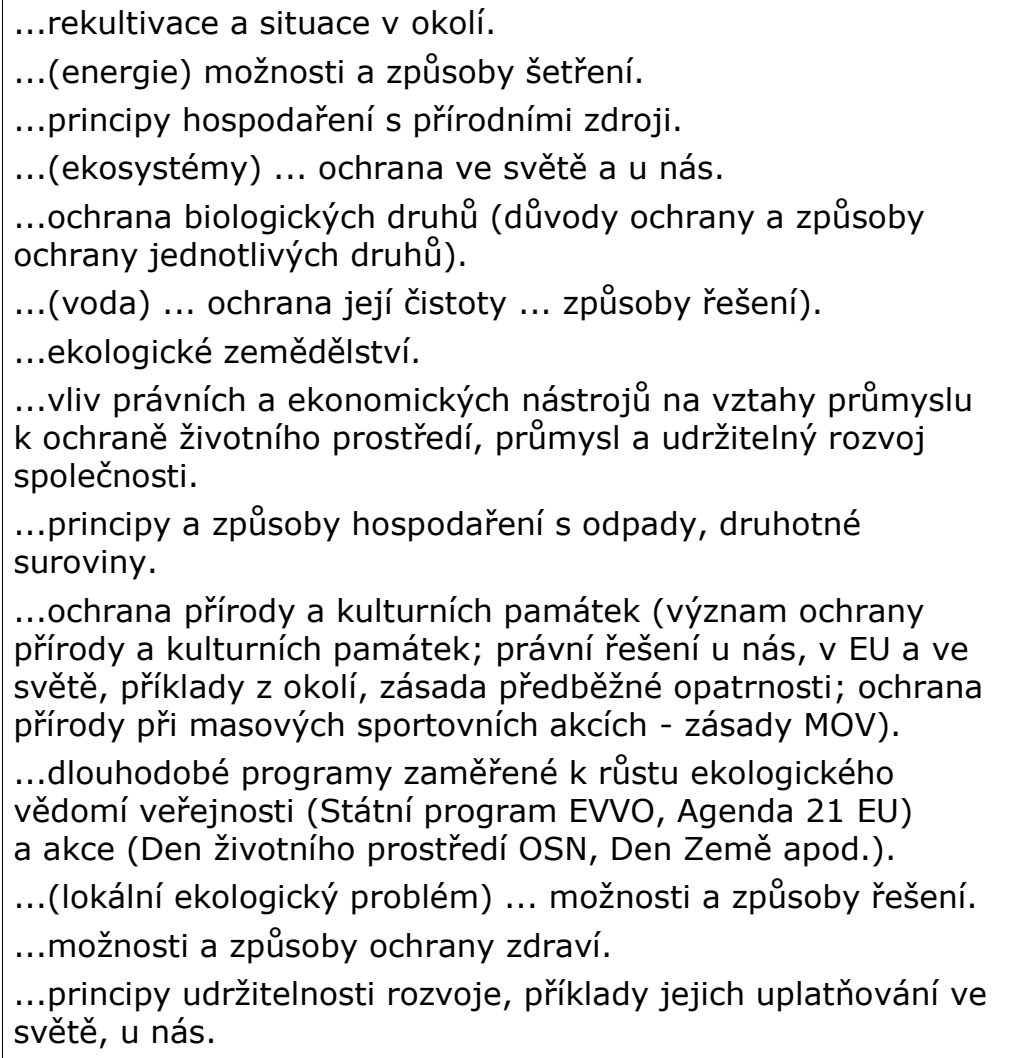 \\
\hline Komunitní problematika & $\begin{array}{l}\text {...naše obec (přírodní zdroje, jejich pưvod, zpưsoby využívání } \\
\text { a řešení odpadového hospodářství, príroda a kultura obce a její } \\
\text { ochrana, zajišt́ování ochrany životního prostředí v obci - } \\
\text { instituce, nevládní organizace, lidé). } \\
\text {....aktuální (lokální) ekologický problém (příklad problému, jeho } \\
\text { přičina, dưsledky, souvislosti...). }\end{array}$ \\
\hline Znalost akčních strategií & $\begin{array}{l}\text {...náš životní styl (spotřeba věcí, energie, odpady, způsoby } \\
\text { jednání a vlivy na prostředí). }\end{array}$ \\
\hline \multicolumn{2}{|l|}{ Konativní (dovednosti) } \\
\hline Akční kompetence & $\begin{array}{l}\text {...(lokální ekologický problém) vlastní názor, jeho } \\
\text { zdůvodňování a prezentace. }\end{array}$ \\
\hline
\end{tabular}


V další fázi byly kódy cílů propojeny se souvisejícími kódy výstupů a učiva. Výsledkem byl vznik uspořádaných entit "cíle-výstupy-učivo". Protože kompletní triáda se skládá ze dvou funkčních vazeb, byly triády následně ohodnoceny dvěma body. Jeden bod získaly dyády, ve kterých jeden z prvků (cíle, výstupy či učivo) chyběl. Monády, kódy bez vazby na kódy v jiných kategoriích, nebyly hodnoceny žádným bodem.

Protože chování žáků může být cílem i výstupem kurikula, ale nikoliv obsahem učiva, mají kompletní entity na rovině chování pouze dyadický charakter a jsou hodnoceny jedním bodem.

Index vnitřní konzistence PT EV pak byl vypočten jako poměr mezi maximálním možným a získaným počtem bodů. Vztahy mezi kategoriemi cílů, výstupů a učiva $v$ prưřezovém tématu jsou znázorněny $v$ tabulce č. 8 :

Tab. č. 8. Přehled uspořádaných entit cíle-výstupy-učivo.

\begin{tabular}{|c|c|c|c|}
\hline Cíle & Výstupy & Učivo & Body \\
\hline \multicolumn{4}{|l|}{ Kognitivní } \\
\hline \multirow{2}{*}{$\begin{array}{l}\text { Porozumění } \\
\text { provázanosti člověka a } \\
\text { prostředí }\end{array}$} & Ekologické principy & Ekologické principy & 2 \\
\hline & Člověk a prostředí & $\begin{array}{l}\text { Člověk a ekosystémy } \\
\text { Ekonomické aktivity }\end{array}$ & 2 \\
\hline $\begin{array}{l}\text { Znalost akčních } \\
\text { strategií }\end{array}$ & $\begin{array}{l}\text { Znalost akčních } \\
\text { strategií }\end{array}$ & $\begin{array}{l}\text { Strategie řešení problémů } \\
\text { Znalost akčních strategií }\end{array}$ & 2 \\
\hline- & - & Typy ekosystémů & 0 \\
\hline- & - & Složky životního prostředí & 0 \\
\hline- & - & Komunitní problematika & 0 \\
\hline \multicolumn{4}{|c|}{ Afektivní (postoje a hodnoty) } \\
\hline $\begin{array}{l}\text { Přijetí udržitelného } \\
\text { rozvoje }\end{array}$ & $\begin{array}{l}\text { Souhlas s konceptem } \\
\text { udržitelného rozvoje }\end{array}$ & - & 1 \\
\hline $\begin{array}{l}\text { Přijetí vlastní } \\
\text { odpovědnosti }\end{array}$ & Vědomí odpovědnosti & - & 1 \\
\hline Hodnoty & $\begin{array}{l}\text { Environmentální } \\
\text { senzitivita }\end{array}$ & - & 1 \\
\hline \multicolumn{4}{|l|}{ Konativní (dovednosti) } \\
\hline- & Výzkumné dovednosti & - & 0 \\
\hline- & Akční kompetence & Akční kompetence & 1 \\
\hline \multicolumn{4}{|l|}{ Chování } \\
\hline \multirow{3}{*}{$\begin{array}{l}\text { Proenvironmentální } \\
\text { chování }\end{array}$} & Ekomanagement & $x$ & 1 \\
\hline & Zdravý životní styl & $x$ & 1 \\
\hline & $\begin{array}{l}\text { Politicko-právní } \\
\text { chování }\end{array}$ & $x$ & 1 \\
\hline
\end{tabular}




\begin{tabular}{|c|c|}
\hline Celkový počet uspořádaných entit: & 14 \\
\hline Maximální možné skóre: & 25 \\
\hline Skutečný bodový zisk: & 13 \\
\hline Index vnitřní konzistence standardu (\%): & 52 \\
\hline
\end{tabular}

Pozn.: Chybějící vazba je znázorněna znakem „-". Symbol "x" byl užit pro dyadické entity cíle-výstupy u kódů chování.

Vnitřní konzistence vztahů mezi cíli, výstupy a učivem podle průřezového tématu je zhruba padesátiprocentní. PT EV dobře provazuje cíle, výstupy a učivo $v$ oblastech porozumění provázanosti a znalosti akčních strategií. $\vee$ oblasti chování deklaruje zájem o oblast ekomanagementu a politicko-právní chování. Diskutabilní je zařazení zdravého životního stylu jako typu proenvironmentálního chování.

Průřezové téma naopak nedostatečně provazuje afektivní a konativní kategorie. $\mathrm{Na}$ úrovni cílů $\mathrm{i}$ výstupů jsou deklarovány postoje, které nenachází oporu $\mathrm{v}$ učivu. Přestože některé postoje múže být skutečně obtižné do učiva zahrnout a jiné mohou být neprímým výsledkem jinak zaměřené výuky, je otázka, zda by např́iklad environmentální senzitivitě či „souhlasu s konceptem udržitelného rozvoje" nemohlo odpovídat samostatné učivo.

PT EV dále předpokládá výstupy $v$ oblasti výzkumných a akčních dovedností. S těmi ale nekorespondují cíle kurikula. Výzkumné dovednosti navíc nemají oporu v učivu.

Průřezové téma dále zařazuje do tématických okruhů učivo, které nekoresponduje s cíli ani výstupy.

Cíle, výstupy a učivo nejsou dostatečně provázány. Škola, která zpracuje svůj školní vzdělávací program přesně podle doporučení v RVP, pravděpodobně nedosáhne některých $z$ deklarovaných cílư a výstupů, pro které nenajde oporu $v$ učivu. Současně se bude zabývat tématikou, která směřuje $\mathrm{k}$ naplnění jiných cílů a výstupů, než jsou ty deklarované.

\section{Analýza hodnotové orientace prưřrezového tématu}

Každé standardy odráží hodnoty společnosti, která je přijala. Ty se projevují v nastavení cílů, výstupů, učiva i v jazyce, kterým jsou prezentovány. Současná společnost klade důraz na toleranci k různým hodnotovým systémům, což odráží i RVP (2007:11). Obdobně standardy Severoamerické asociace pro environmentální výchovu vyžadují, aby programy a materiály byly "kulturně i genderově senzitivní a inklusivní a "udržovaly rovnováhu mezi různými úhly pohledu a teoriemi". (Simmons, 2004)

$\checkmark$ hodnocení průřezového tématu se zaměříme na environmentálně etické paradigma vyjadřované dokumentem. Erazim Kohák (2006) vymezil čtyři hlavní etická paradigmata ve vztahu člověka k životnímu prostředí:

- Antropocentrismus, podle kterého je člověk zdrojem hodnot a príroda má proto hodnotu pouze instrumentální.

- Teocentrismus, podle kterého je zdrojem hodnot Bůh a jednání člověka vůči př́rodě je vymezeno jeho vưlí.

- Biocentrismus, který chápe život jako intrinsickou hodnotu. 
- Ekocentrismus, podle kterého má celek (ekosystém) $\mathrm{v}$ oprávněných případech vyšší hodnotu než jednotlivec.

Přestože antropocentrismus připouští interpretace vedoucí k environmentálně odpovědnému chování, podle některých teorií korelují s proenvironmentálním chováním spíše neantropocentrické hodnoty (Stern, 2000; Stern et. al, 1999). V rámci analýzy průřezového tématu se proto pokusíme posoudit, zda jako celek odráží spíše antropocentrické či neantropocentrické (tj. bio-, eko-, teocentrické) hodnoty, př́padně zda je téma eticky neutrální.

Prvním krokem byla opět analýza sémantických jednotek z Charakteristiky, Př́nosů a Tématických okruhů. Do kategorie "Antropocentrismus" byly zařazeny jednotky vyjadřující instrumentální hodnotu přírody, tj. jednotky vyjadřující možnosti využití prírody člověkem. Do kategorie "Neantropocentrismus" byly zařazeny jednotky vyjadřující intrinsickou hodnotu prírody, tj. její na člověku nezávislé kvality. Neutrální sémantické jednotky nejsou $v$ analýze uváděny. Přehled eticky zabarvených sémantických jednotek je uveden $v$ tabulce č. 9.

Tab. č. 9. Přehled eticky zabarvených sémantických jednotek.

\begin{tabular}{|c|c|c|}
\hline Antropocentrismus & Neantropocentrismus & Nerozlišitelné \\
\hline $\begin{array}{l}\text {...produkční a } \\
\text { mimoprodukční významy } \\
\text { lesa. } \\
\text {...(tropický deštný les) ... } \\
\text { význam pro nás. } \\
\text {...význam vody pro lidské } \\
\text { aktivity. } \\
\text {...zdroje surovinové a } \\
\text { energetické, principy } \\
\text { hospodaření s prírodními } \\
\text { zdroji. }\end{array}$ & $\begin{array}{l}\text {...přispívá k vnímání života } \\
\text { jako nejvyšší hodnoty. } \\
\text {...vodní zdroje - důležitost pro } \\
\text { krajinnou ekologii. } \\
\text {...význam (moře) pro biosféru. } \\
\text {...(tropický deštný les) ... } \\
\text { globální význam. } \\
\text {...(ovzduší) význam pro život } \\
\text { na Zemi. } \\
\text {...energie a život. }\end{array}$ & $\begin{array}{l}\text {...(pole) ... význam. } \\
\text {...vnímání estetických } \\
\text { hodnot prostředí. } \\
\text {...(půda) ... zdroj výživy } \\
\text {...funkce ekosystémů, } \\
\text { význam biodiverzity. }\end{array}$ \\
\hline 4 & 5 & 4 \\
\hline
\end{tabular}

Naprostá většina sémantických jednotek je hodnotově neutrální. V PT EV je možné najít čtyři jednotky s antropocentrickým zabarvením, vymezujícím př́rodu jako zdroj pro člověka. Oproti tomu pět sémantických jednotek definuje důležitost prírody ve vztahu $\mathrm{k}$ jiným složkám př́rody. Z toho čtyři jednotky jsou výrazně ekocentrické a jedna biocentrická. Je třeba zmínit, že zařazení jednotky „přispívá k vnímání života jako nejvyšší hodnoty" do neantropocentrické kategorie není zcela prosto pochyb, nebot́ není výslovně uvedeno, zda se jedná o jakýkoliv život či pouze lidský život. Mezi "nerozlišitelné" byly zařazeny jednotky, u kterých není zřejmý adresát významu a text proto připouští obě možnosti (tj. pro člověka i pro všechen život). Do stejné kategorie byla zařazena i jednotka „vnímání estetických hodnot prostředí", protože nelze jednoznačně rozhodnout, zda vyjadřuje přesvědčení o kráse př́rody jako kategorii definovanou lidmi či kráse jako svébytného projevu života nezávislého na člověku.

Celkově je možné PT EV hodnotit jako eticky vyvážený a nestranící žádnému z etických paradigmat.

\section{Korespondence PT s teoriemi proenvironmentálního chování}

Hlavním cílem environmentální výchovy je environmentálně odpovědné chování veřejnosti. Proenvironmentální chování jako cíl obsahuje i prưřezové téma: „vede jedince 
k aktivní účasti na ochraně a utváření prostředí a ovlivňuje v zájmu udržitelnosti rozvoje lidské civilizace životní styl a hodnotovou orientaci žáků." (RVP:99)

Proenvironmentální chování se nejčastěji v zahraniční literatuře člení do pěti oblastí:

- Ekomanagement, chápaný jako jednání, kterým lidé přímo ovlivňují stav životního prostředí, aby řešili určitý environmentální problém či mu předcházeli.

- Spotřebitelské chování, při kterém lidé využívají svou kupní sílu k ovlivňování průmyslu a obchodu směrem k environmentálně odpovědné produkci.

- Přesvědčování, při kterém lidé působí na jiné osoby či skupiny ve snaze zapojit je do řešení environmentálních problémů.

- Politické akce, při kterých občané využívají politické procesy, organizace či úrady.

- Právní akce, ve kterých občané využívají existující legislativní nástroje k řešení či prevenci environmentálních problémů (Marcinkowski, 1997).

Ve výstupech RVP tomuto rozdělení odpovídají tři kategorie:

- Ekomanagement

- Zdravý životní styl

- Politicko-právní chování

Zařazení zdravého životního stylu do kategorií proenvironmentálního chování je problematické. Je zřejmé, že zdravý životní styl může mít pozitivní, neutrální i negativní dopady na životní prostředí. Pro tělesnou kondici např́klad mưže být zdravé věnovat se sjezdovému lyžování, výstavba sjezdovek současně poškozuje krajinu a narušuje lesní ekosystémy. V zimě může být zdravé jíst tropické ovoce kvưli vitamínům, dovoz $z$ velké vzdálenosti současně znamená vysokou ekologickou bilanci takového stravování. $Z$ tohoto důvodu se nebudeme touto kategorií dále zabývat.

V RVP chybí ekvivalent ke spotřebitelskému chování a k přesvědčování. Nepř́tomnost spotřebitelského chování jako cílové oblasti proenvironmentálního chování je zarážející vzhledem k tomu, že žáci základní školy již disponují finančními zdroji a jejich ovlivňování v této oblasti je proto nejenom žádoucí, ale i relevantní.

Většina autorů $v$ současnosti předpokládá, že pro ovlivnění environmentálního chování nestačí pouze ovlivňovat znalosti žáka, ale že chování je funkcí řady proměnných (Disinger, 1997; Hines, Hungerford \& Tomera, 1986-7; Hungerford \& Volk, 1990). Pro posouzení, zda průřezové téma pokrývá proměnné ovlivňující proenvironmentální chování byl využit model Hungerford-Volková (1990), okrajově value-belief-norm theory Paula Sterna (2000) a teorie plánovaného chování Iceka Ajzena (1991).

Podle teorie Hungerforda a Volkové (1990) je proenvironmentální chování výsledkem tř́i typů proměnných: vstupních, vlastnických a proměnných vlivu. Každý z typů pak obsahuje několik proměnných, které jsou dále děleny na hlavní a vedlejší. Vyhodnocení prưřezového tématu podle tohoto modelu zachycuje obrázek č. 1 : 
Obr. č. 1. Analýza zastoupení proměnných v PT EV na modelu HungerfordVolková.

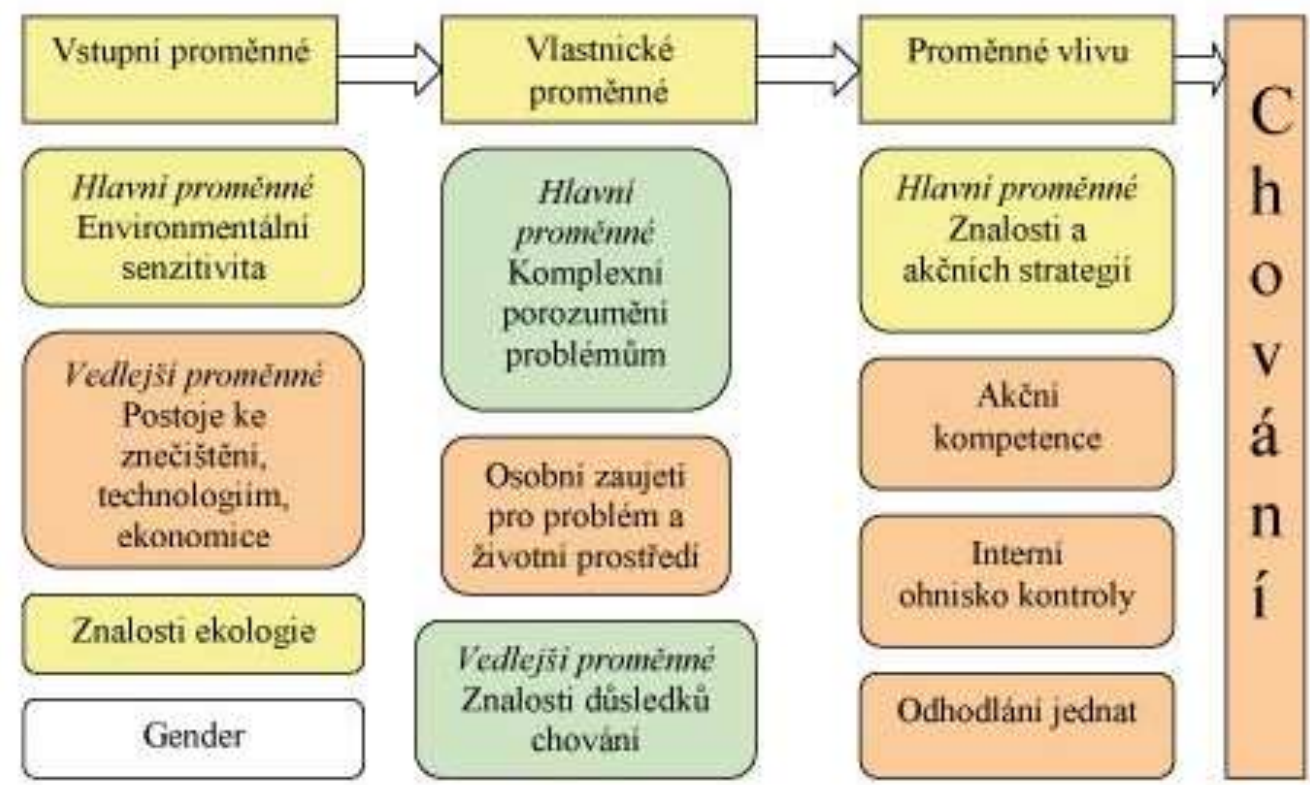

Legenda: Bílé pozadí mají proměnné, které není možné v rámci výuky přímo ovlivňovat. Zelené pozadí mají proměnné, které jsou $v$ prưřezovém tématu dostatečně zastoupeny. Žluté pozadí mají proměnné, které jsou v prưrezovém tématu uvedeny, ale nejsou dostatečně zastoupeny nebo není dostatečný předpoklad, že budou pozitivně ovlivněny jinými proměnnými. (Míra zastoupení tématu byla odvozena z výsledků komparace s Environmental Education Curriculum Inventory.) Červené pozadí mají proměnné, které jsou výsledkem jiných proměnných, a současně nelze zcela předpokládat, že budou dostatečně ovlivněny, a dále proměnné, které nejsou v prưřezovém tématu zastoupeny vůbec či jen epizodicky

PT EV pokrývá všechny tři roviny proměnných modelu. Současně žádnou z nich nepokrývá úplně. Prưřezové téma sice deklaruje mezi svými výstupy proměnné spojované s environmentální senzitivitou, té ale neodpovídá žádné téma. Školy, které nenajdou vlastní cestu knaplnění tohoto výstupu, proto tuto nezávisle proměnnou neovlivní. Environmentální senzitivita je přitom nejsilnější proměnná z této skupiny. Určuje motivaci dětí k environmentální problematice.

Postoje ke znečištění, technologiím či ekonomice nejsou přímo uvedeny v cílech ani výstupech. Lze ale předpokládat jejich pozitivní ovlivnění v dưsledku rozsáhlého pokrytí učiva v kategoriích Člověk a ekosystémy a Ekonomické aktivity. Podle Ajzena (1991) vycházejí postoje z přesvědčení jedince o důsledcích určitého chování. $V$ obou zmíněných kategoriích je vazba chování - dưsledky zastoupena.

Znalosti ekologie jsou sice ve standardu rozsáhle zastoupeny, namísto porozumění principům se zde ale klade důraz na popisy složek životního prostředí. Znalosti ekologie neovlivňují podle modelu Hungerford-Volková (1990) přímo chování, mají však vliv na kvalitu přijatého rozhodnutí. Zde je možné se obávat, že právě tuto schopnost žáci škol, které zpracují svůj školní vzdělávací program důsledně podle PT EV, nebudou mít dostatečně rozvinutou.

Průřezové téma se dále rozsáhle věnuje popisům environmentálních problémů a jejich důsledků. Protože ale nezahrnuje oblast výzkumných dovedností, Ize předpokládat, že žáci nebudou schopni environmentální problémy samostatně zkoumat a analyzovat 
a žádoucím způsobem si je „přivlastnit". V důsledku toho Ize očekávat jak pokles jejich zaujetí pro environmentální problematiku, tak i ohrožení míry komplexnosti porozumění prezentovaným problémům.

PT EV sice věnuje poměrně značný prostor přehledu akčních strategií, v naprosté většině se ale jedná o strategie na úrovni státní či podnikové sféry. Jedinou sémantickou jednotkou („spotřeba věcí, energie, odpady, způsoby jednání a vlivy na prostředí") jsou zastoupeny strategie relevantní pro osobní sféru a životní styl v oblasti ekomanagementu.

Akční kompetence jsou v tematických okruzích zastoupeny zcela marginálně („vlastní názor, jeho zdůvodňování a prezentace"). Celá oblast proměnných vlivu posiluje spíše externí než interní ohnisko kontroly. Akčním znalostem a dovednostem žáků je ve standardu věnován nesrovnatelně menší prostor, než strategiím uplatnitelných státní či podnikovou sférou. Pokud tento nepoměr zůstane zachován i ve školních vzdělávacích programech, hrozí, že si z něj žáci odnesou pocit, že problémy životního prostředí se řeší „vně" jejich vlivu, na úrovni státu a že jako jedinci mají jen nepatrné možnosti cokoliv ovlivnit. Důsledkem pak může být nízké odhodlání jednat, lze tedy předpokládat zanedbatelný vliv školního kurikula na environmentální chování žáků.

Porovnáme-li tento závěr s Ajzenovou teorií plánovaného chování (1991), dostaneme podobný výsledek (viz obrázek č. 2):

Obr. č. 2. Analýza zastoupení proměnných v průřezovém tématu na modelu Teorie plánovaného chování.

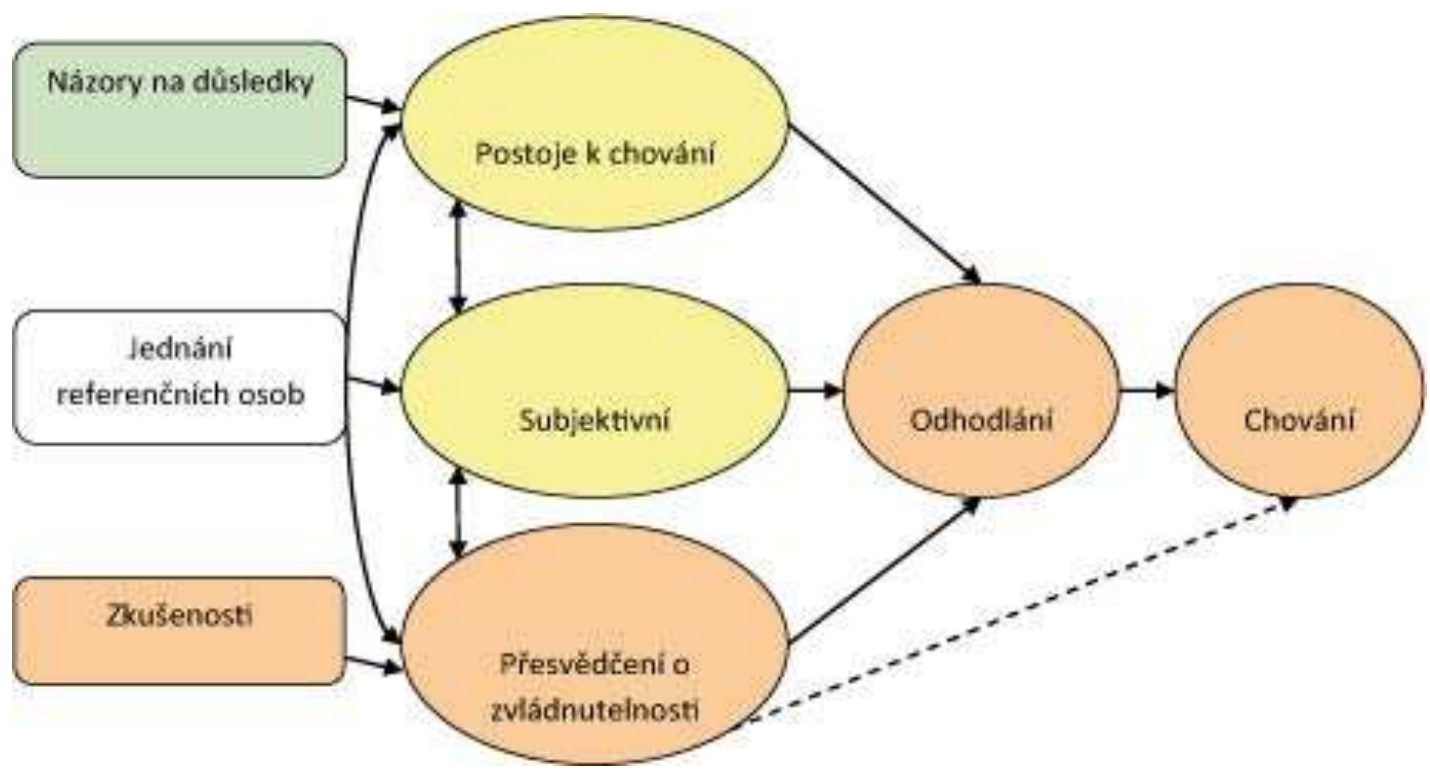

Legenda: Bílé pozadí mají proměnné, které není možné v rámci výuky přímo ovlivňovat. Zelené pozadí mají proměnné, které průřezové téma dostatečně ovlivňuje. Žluté pozadí mají proměnné, které jsou v prưřezovém tématu uvedeny, ale nejsou dostatečně zastoupeny nebo není dostatečný předpoklad, že budou pozitivně ovlivněny jinými proměnnými. Červené pozadí mají proměnné, které jsou výsledkem jiných proměnných, a současně nelze zcela předpokládat, že budou dostatečně ovlivněny; a dále proměnné, které nejsou $v$ průřezovém tématu zastoupeny vůbec či jen epizodicky. 
Prưřezové téma má potenciál na ovlivňování přesvědčení žáků o důsledcích určitého chování. Postoje k chování jsou ale dále ovlivňovány subjektivními normami žáků, a také subjektivně vnímaným přesvědčením o zvládnutelnosti určitého chování. Na subjektivní normy má mj. vliv přesvědčení žáků o tom, jak by se $v$ dané situaci zachovaly jejich referenční osoby. Na tuto proměnnou má učitel pouze omezený vliv za předpokladu, že je pro některé žáky sám takovou referenční osobou. Důležitou proměnnou je i přesvědčení žáků o tom, že je v jejich silách dané chování zvládnout. Kromě subjektivních norem a postojů zde hrají vliv zkušenosti, které žáci s daným chováním mají. Pokud kurikulum není "akčně orientované", žáci tyto zkušenosti nezískají a nebudou věřit tomu, že dané jednání zvládnou. Protože průřezové téma dává rozvíjení akčních kompetencí jen malý prostor, Ize se obávat, že tento problém nastane i ve školách, které se podle něj budou ř́dit. Lze rovněž předpokládat, že žáci pravděpodobněji budou volit snazší aktivity, jako je například třídění odpadů, než chování vyžadující vyšší míru akčních dovedností (např. výběr ekologicky př́iznivějších výrobků, kontaktování úřadů kvůli environmentálním konfliktům atd.).

Podle Sternovy $(1999,2000)$ value-belief-norm teorie jsou základním východiskem proenvironmentálního chování altruistické, resp. biocentrické a ekocentrické hodnoty. Ty vedou $\mathrm{k}$ přijetí proenvironmentálních postojů, které otevírají jedince $\mathrm{k}$ uvědomování si existence environmentálních problémů a přijetí norem osobní odpovědnosti za zapojení se do jejich řešení. Výsledné chování pak ovlivňuje řada dalších faktorů, jako např. sociální status, vzdělání, dovednosti, finanční zdroje a další. Pokud by prưřezové téma vycházelo $z$ této teorie, muselo by důsledně akcentovat biocentrické a ekocentrické postoje a naopak potlačit antropocentrické hodnoty. Z hlediska hodnotové orientace bylo ale PT EV hodnoceno jako vyvážené. Většina sémantických jednotek byla hodnocena jako neutrální, počet antropocentricky či neantropocentricky zabarvených jednotek byl v rovnováze. Nelze proto předpokládat, že prưřezové téma bude výrazně působit na žáky směrem k neantropocentrickým hodnotám.

Prưřezové téma deklaruje zájem ovlivňovat chování žáků. Ve vymezení výstupů ale nepokrývá všechny klíčové oblasti proenvironmentálního chování. Nezávisle proměnné, které obsahuje, současně nejsou dostatečně silně zastoupeny pro to, aby takové chování ovlivnily. Žáci škol, které zpracují své školní programy přesně podle prưřezového tématu, se proto pravděpodobně budou chovat stejně, jako kdyby školním programem environmentální výchovy neprošli. Výjimkou mohou být relativně jednoduché oblasti chování (např. třídění odpadu, nevyhazování odpadků na nesprávných místech), které vyžadují jen minimální stupeň dovedností a pro které se žák mưže rozhodnout na základě informací o důsledcích takového jednání.

\section{Diskuse a závěry}

Analýza průřezového tématu přinesla tato hlavní zjištění:

- Prưřezové téma není kompatibilní se široce rozšířeným zahraničním standardem.

- $\quad V$ průřezovém tématu nejsou dostatečně zastoupeny dovednosti.

- $\quad V$ ekologické tématice se PT EV soustředí na popisy složek životního prostředí a typy ekosystémů, zatímco zahraniční standard především na ekologické principy a procesy. Tato oblast je v PT EV naopak poměrně málo zastoupena.

- PT EV oproti zahraničnímu nerozlišuje mezi environmentálními problémy a konflikty.

- PT EV vyžaduje povinné zohlednění tematických okruhů, ale nikoliv cílů a výstupů. 
- Vnitřní konzistence průřezového tématu je zhruba padesátiprocentní. V některých př́padech deklaruje cíle a výstupy, ale neuvádí odpovídající učivo. To se týká zejména afektivní roviny, která tak získává poněkud proklamativní nádech. $v$ jiných prípadech uvádí učivo bez vztahu $\mathrm{k}$ cílům a výstupům.

- Prưřezové téma je eticky vyvážené a nepřiklání se ani k antropocentrickým ani k neantropocentrickým hodnotám.

- Prưřezové téma mezi deklarovanými cíli $v$ oblasti chování neuvádí některé klíčové oblasti chování, zejména spotřebitelství.

- Prưřezové téma sice deklaruje mezi cíli formování proenvironmentálního chování žáků, vzhledem $\mathrm{k}$ nedostatečnému zastoupení některých klíčových proměnných je pozitivní vliv odvozených školních kurikulí pravděpodobný pouze u chování vyžadujícího velmi nízkou míru souvisejících dovedností.

Uvedená zjištění by měla být podrobena dalšímu ověřování. Je zřejmé, že jejich potvrzení či vyvrácení může $v$ plné miře přinést až výzkum, který by hodnotil environmentální gramotnost ${ }^{2}$ žáků $\vee$ posledních ročnících základní školy a porovnával ji s mírou shody školního vzdělávacího programu s průřezovým tématem. Takový výzkum je ale proveditelný až $s$ odstupem několika let, protože základní školy teprve před rokem zahájily výuku podle RVP. Je ale možné začít alespoň s dílčími výzkumy problematiky.

Hodnocení bylo provedeno jediným hodnotitelem. Přiřazování sémantických jednotek ke kódům proto mohlo být subjektivně ovlivněno. Z tohoto důvodu obsahuje článek kompletní rozřazovací tabulky a umožňuje tak nezávislé posouzení a ověření použité metodiky.

Provedená analýza vycházela z porovnávání PT EV se zahraniční teorií a nástroji, které $z$ těchto teorií a souvisejících výzkumů vycházejí. Takové porovnání s sebou vždy nese rizika nekompatibility s českými reáliemi. Z RVP není bohužel zjevné, na základě jakých relevantních teorií environmentální výchovy výzkumný ústav pedagogický prưřezové téma vytvořil. Je ale možné předpokládat, že česká specifika nejsou natolik odlišná od standardů uplatňovaných v euroamerickém okruhu, aby vysvětlovala tak vysokou míru odlišností českého standardu od zahraničních modelư.

Nabízí se proto otázka, zda čekat několik let na otevření možnosti plnohodnotně PT EV experimentálně ověřit, či zda by nebylo na místě otevř́t diskusi o jeho přepracování.

\section{Literatura}

- Ajzen, I. (1991). The Theory of Planned Behavior. Organizational Behavior and Human Decision Process, 50, 179-211.

- Ardoin, N. M. . Sense of Place and Responsible Behavior: What the Research Says. : Yale School of Forestry and Environmental Studies. Retrieved from http://www.naaee.org/conferences/biloxi/n ardoin 3 10008a.pdf

\footnotetext{
${ }^{2}$ Environmentální gramotnost se zde chápe jako podle vymezení Disingera (1997) a Moseleyho (2000) jako schopnost rozeznat a poskytnout pracovní definice základních pojmů o životním prostředí (nominální úroveň), širší porozumění přírodě a environmentálním interakcím (funkční úroveň) a dovedností, schopnost rozpoznat environmentální rizika, pracovat s informacemi, zaujímat stanoviska a promítat je do vlastního jednání (operační úroveň).
} 
- Bennett, D. B. (1989). Evaluating Environmental Education in Schools. A practical guide for teachers. : UNESCO-U NEP, Division of Science, Technical and Environmental Education. Retrieved from http://unesdoc.unesco.org/images/0006/000661/066120eo.pdf

- Disinger, J. F. (1997). Environment in the K-12 Curriculum: An Overview. InWILKE, Richard J. Environmental Education. Teacher Ressource Handbook. A Practical Guide for K-12 Environmental Education. Thousand Oaks: Corwin.

- Dlouhá, R. (2004). Analýza Rámcového vzdělávacího programu pro gymnaziální vzdělávání z pohledu globálního rozvojového vzdělávání. Praha: Člověk $v$ tísni. Retrieved from http://www.varianty.cz/download/doc/stats/GrvE.pdf

- Does Your Project Make a Difference? (2004). Sydney: Department of Environment and Conservation. Retrieved from http://www.environment.nsw.gov.au/resources/community/projecteval04110.pdf

- $\quad$ EMMONS Katherine M, (1997). Perspectives on Environmental Action: Reflection and Revision Through Practical Experience. Journal of Environmental Education, 28(1), 34-44. Retrieved from $\quad$ http://www.tandfonline.com/doi/abs/10.1080/00958969709599105 http://dx.doi.org/10.1080/00958969709599105

- Excellence in Environmental Education - Guidelines for Learning (Pre K-12) (2004). Rock Spring, GA: North American Association for Environmental Education. Retrieved from http://www.naaee.org/npeee/learner guidelines.php

- Hines, J. M., Hungerford, H. R., \& Tomera, A. N. (1986). Analysis and Synthesis of Research on Responsible Environmental Behavior: A Meta-Analysis. The Journal of Environmental Education, 18(2), 1-8.

- Hodnotící tabulka (2008). Praha: SSEV Pavučina.

- Hogan, C. (2003). Practical facilitation. A toolkit of techniques. London: Kogan Page.

- Hornová, K. (2006). Environmentální výchova jako prưřezové téma vzdělávacích programů pro ZŠ a nižši stupně gymnázia. Praha. Retrieved from http://web.natur.cuni.cz/kudbi/soubory/prace didaktika.pdf

- Hungerford, H., Peyton, R. Ben,,', \& Wilke, R. J. (1980). Goals for Curriculum Development in Environmental Education. The Journal of Environmental Education, 11(3), 42-47. Retrieved from $\quad$ http://www.tandfonline.com/doi/abs/10.1080/00958964.1980.9941381 http://dx.doi.org/10.1080/00958964.1980.9941381

- Hungerford, H. R., \& Volk, T. L. (1990). Changing Learner Behavior Through Environmental Education. The Journal of Environmental Education, 21(3), 8-21. Retrieved from http://www.tandfonline.com/doi/abs/10.1080/00958964.1990.10753743 http://dx.doi.org/10.1080/00958964.1990.10753743

- Kim, K. O. (2003). An inventory for assessing environmental education curricula. The Journal of Environmental Education, 34(2), 12-18. Retrieved from http://www.tandfonline.com/doi/abs/10.1080/00958960309603495 http://dx.doi.org/10.1080/00958960309603495

- Kohák, E. (2006). Zelená svatozár̆. Praha: Slon.

- Kožoušková, A. (2007). Environmentální prístup ke vzdělávání na 1. stupni základní školy. Brno: Masarykova univerzita.

- Kvasničková, D. .Výroční zpráva Klubu ekologické výchovy. . Retrieved from http://www.generalhonza.wz.cz/vz2007.pdf

- Máchal, A., Činčera, J., Daňková, L., \& Broukal, V. (2008). Ekopedagogovo osmero 2007. Praha: Pavučina.

- Marcinowski, T. (1997) Assessment in Environmental Education. In R. J. Wilke (Ed.), Environmental Education. Teacher Ressource Handbook. Thousand Oaks: Corwin. 
- Metodický pokyn MŠMT k zajištění environmentálního vzdělávání, výchovy a osvěty (2008). Praha: Ministerstvo školství, mládeže a tělovýchovy.

- Metodický portál RVP (2005). Praha: Výzkumný ústav pedagogický. Retrieved from http://www.rvp.cz

- Mogensen, F. . Environmental education - development and evaluation. : The Royal Danish School of Educational Studies. Retrieved from http://nibis.ni.schule.de/ beckmann/health/booklet/ee start.htm

- Moseley, C. (2000). Teaching for environmental literacy. The Clearing House, 74(1), 23-24.

- Östman, L., \& Öhman, J. (2007). Selective traditions within Environmental Education. Durban: World Environmental Education Congress.

- Rámcový vzdělávací program pro základní vzdělání (2007). Praha: Výzkumný ústav pedagogický.

- Ekoškola, S. T. . Kritéria pro získání titulu Ekoškola. : Sdružení TEREZA Ekoškola. Retrieved from http://ekoskola.cz/images/stories/materialy/kriteria.pdf

- Sellers, J. Goals. In MEERA Evaluation Glossary. . Retrieved from http://meera.snre.umich.edu

- Schueller, S. K., Yaffee, S. L., Higgs, S. J., Mogelgaard, K., \& DeMattia, E. A. (2006). Evaluation Sourcebook: Measures of Progress for Ecosystem- and Community-Based Projects. Ann Argot: Ecosystem Management Initiative, University of Michigan.

- Simmons, B. . Designing Evaluation for Education Projects. : Office of Education and Sustainable Development. Retrieved from http://wateroutreach.uwex.edu/use/documents/NOAAEvalmanualFINAL.pdf

- Simmons, B. (2004). NONFORMAL Environmental Education Programs: Guidelines for Excellence. : North American Association for Environmental Education. Retrieved from http://naaee.org/npeee/nonformal/nonformalguidelines.pdf

- STERN Paul C, (2000). Toward a Coherent Theory of Environmentally Significant Behavior. Journal of Social Issues, 56(2000), 407-424. Retrieved from http://doi.wiley.com/10.1111/0022-4537.00175 http://dx.doi.org/10.1111/0022$\underline{4537.00175}$

- Stern, P. C., Dietz, T., Troy, A., Guagnano, G. A., \& Kalof, L. (1999). A Value-Belief-Norm Theory of Support for Social Movements: The Case of Environmentalism. Human Ecology Review, 6(6), 81-97.

- VOLK, Trudi. L., (1997) Integration and Curriculum Design. In R. J. Wilke (Ed.), Environmental Education. Teacher Ressource Handbook. A Practical Guide for K-12 Environmental Education (pp. 45-76). Thousand Oaks: Corwin.

- Vyhláška č. 317/2005 Sb. o studiu k výkonu specializovaných činností. . .

- Žárská, M., Ermlová, M., Kupka, O., Klápště, P., Zajíc, J., \& Šantora, R. (2008). Jak pracovat se stezkou. Praha: Junák. 
Časopis Envigogika vydává Centrum pro otázky životního prostředí UK. Vývoj časopisu je podpořen projektem OP VK Mezioborová sít udržitelného rozvoje.

Více najdete na internetových stránkách projektu mosur.czp.cuni.cz
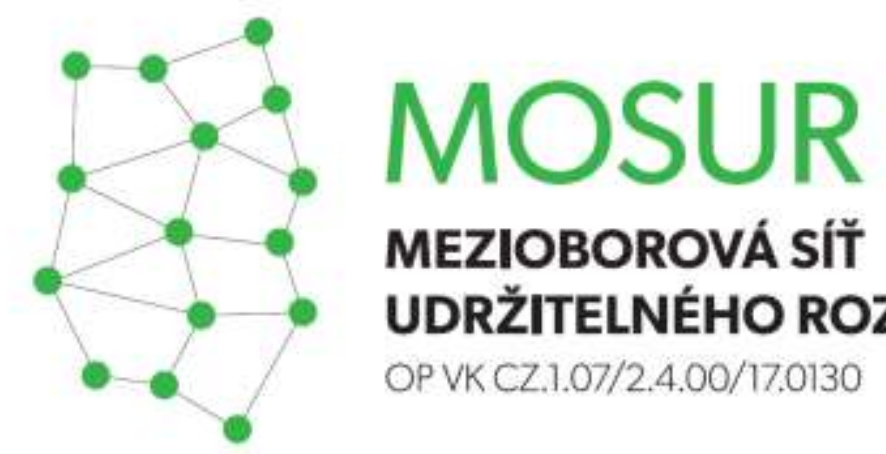

\section{MEZIOBOROVÁ SÍT} UDRŽITELNÉHO ROZVOJE

OP VK CZ.1.07/2.4.00/17.0130
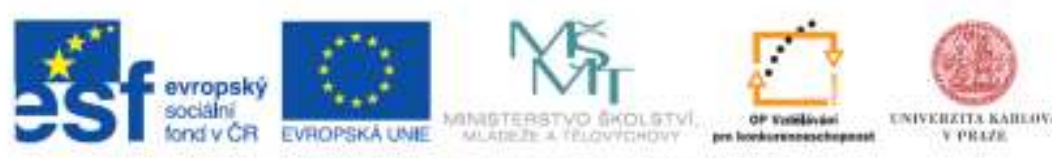

INVESTICE DO ROZVOJE VZDELAVANI 